\title{
Anaerobic Co-Digestion Effluent as Substrate for Chlorella vulgaris and Scenedesmus obliquus Cultivation
}

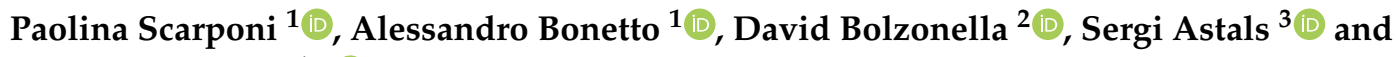 \\ Cristina Cavinato $1, * \mathbb{D}$ \\ 1 Department of Environmental Sciences, Informatics and Statistics, University Ca' Foscari of Venice, \\ via Torino 155, 30172 Venice, Italy; paolina.scarponi@unive.it (P.S.); alessandro.bonetto@unive.it (A.B.) \\ 2 Department of Biotechnology, University of Verona, Strada le Grazie 15, 37134 Verona, Italy; \\ david.bolzonella@univr.it \\ 3 Department of Chemical Engineering and Analytical Chemistry, University of Barcelona, \\ 08028 Barcelona, Spain; sastals@ub.edu \\ * Correspondence: cavinato@unive.it
}

Received: 31 August 2020; Accepted: 14 September 2020; Published: 17 September 2020

\begin{abstract}
Anaerobic digestate supernatant can be used as a nutrient source for microalgae cultivation, thus integrating phytoremediation processes with high value products storage in microalgae biomass. Microalgae are able to use nitrogen and phosphorous from digestate, but high nutrient concentration can cause growth inhibition. In this study, two microalgae strains (C. vulgaris and S. obliquus) were cultivated on the anaerobic co-digestion supernatant (obtained from the organic fraction of municipal solid waste (OFMSW) and waste activated sludge (WAS)) in a preliminary Petri plate screening at different dilutions (1:10 and 1:5) using a synthetic medium (ISO) and tap water (TW). Direct Nile red screening was applied on colonies to preliminarily identify hydrophobic compound storage and then a batch test was performed (without air insufflation). Results show that $C$. vulgaris was able to grow on digestate supernatant 1:5 diluted, while Nile red screening allowed the preliminary detection of hydrophobic compound storage in colonies. The analysis carried out at the end of the test on ammonia, phosphate, nitrate and sulphate showed a removal percentage of $47.5 \pm 0.8 \%, 65.0 \pm 6.0 \%$, $95.0 \pm 3.0 \%$ and $99.5 \pm 0.1 \%$, respectively.
\end{abstract}

Keywords: digestate; anaerobic co-digestion; anaerobic digestion; microalgae; Chlorella vulgaris; Scenedesmus obliquus

\section{Introduction}

The disposal of anaerobic supernatants can lead to several environmental problems, mainly due to their high nitrogen content. Their direct spreading onto agricultural land can cause nutrient emissions and cause eutrophication of nearby surface and ground waters [1-3] and $\mathrm{NH}_{3}$ volatilization. Moreover, supernatants from digester-treated municipal organic waste and sewage sludge are likely to contain pathogens, heavy metals and microplastics (phthalates contamination) [4,5]. A strategy to mitigate the environmental impact of digestate or to avoid nutrient recirculation within the wastewater treatment plant is to use supernatants as a nutrient source for aquatic microalgae cultivation [6]. Additionally, microalgae cultivation could be coupled with lipid intracellular accumulation for subsequent biodiesel production since microalgae have a short carbon period for lipid storage and a faster photosynthetic efficiency (3-8\%) compared to plant oils (0.5\%) [7].

Microalgae are unicellular microorganisms, with photosynthetic activity and the capacity to grow on a wide variety of nutrient sources, including anaerobic digestion (AD) supernatant [8-10]. The AD effluent composition (i.e., high nitrogen and phosphorus concentration) has positive effects 
on microalgae biomass production and the accumulation of secondary high-value products [10]. Digestates provide some stress growth conditions that could result in high productivity of lipids (30-50\% lipid storage on total dry weight [11]), carbohydrates, pigments and amino acids $[4,12,13]$. In addition, microalgae cultivation on AD supernatant could give some advantages with cost decrease for cultivation (the addition of synthetic nutrient being avoided) and the utilization of AD effluent as a nutrient source [4]. Several kinds of liquid AD digestate (from pig manure [14,15], municipal wastewater [16], vinasse [17] and starch processing wastewater [18]) have been tested for microalgae growth with a dry weight production of $0.4-4.8 \mathrm{~g} \mathrm{~L}^{-1}$ [19] and a biomass production of $0.03-0.9 \mathrm{~g} \mathrm{~L}^{-1} \mathrm{~d}^{-1}$ [20]. Microalgae grown on AD co-digestion effluent (OFMSW and WAS) have not been extensively studied with only a few studies available in the literature, including Cai and Park et al. [16], Cai and Ge et al. [21], Zuliani et al. [9], Dickinson et al. [15], Cho and Thao et al. [22], Uggetti et al. [20] and Cho and Lee et al. [23]. Combinations of pretreatments such as centrifugation, filtration and sterilization have usually been applied to digestates before their use for microalgae cultivation. Nonetheless, the main problem with the use of digestate for microalgae cultivation is the presence of toxic compounds (phenols [24], $\mathrm{NH}_{3}$ [25], nitrite and heavy metals [26]) that can limit microalgae proliferation and accumulation of secondary products $[27,28]$. C. vulgaris and S. obliquus have been widely studied on several kinds of digestate and stand as the most promising microalgae strains with phytoremediation effects linked with secondary high value storage (i.e., lipids, chlorophylls and carotenoids). However, they have different abiotic stresses, such as nutrient starvation, light intensity and salinity $[9,19,26,29,30]$.

In this study, the growth capacity of Chlorella vulgaris and Scenedesmus obliquus (wild type) was tested on OFMSW and WAS liquid digestate after centrifugation to select the most suitable microalgae to remove nitrogen from co-digestion supernatants. Specifically, this study analyzed the effect of digestate dilution (both with synthetic medium (ISO 8692) and tap water (TW)) on biomass growth, chlorophyll production and nutrient removal efficiency.

\section{Material and Methods}

\subsection{Anaerobic Co-Digestion Effluent Characterization}

The digestate was sampled in a municipal wastewater treatment plant (WWTP) in northern Italy, in which anaerobic co-digestion of WAS and OFMSW was applied. Process parameters of the AD plant are reported in Moretto et al. [31]. Digestate characterization is reported in Table 1.

Table 1. Organic fraction of municipal solid waste and waste activated sludge (OFMSW-WAS) digestate characterization $(n=2)$.

\begin{tabular}{cc}
\hline Parameter & \\
\hline $\mathrm{TS}\left(\mathrm{g} \mathrm{kg}^{-1}\right)$ & $18.3 \pm 2.8$ \\
$\mathrm{VS}\left(\mathrm{g} \mathrm{kg}^{-1}\right)$ & $12.7 \pm 2.2$ \\
$\mathrm{pH}$ & $7.6 \pm 0.3$ \\
$\mathrm{sCOD}\left(\mathrm{mg} \mathrm{L}^{-1}\right)$ & $300.0 \pm 119.0$ \\
Partial alkalinity $\left(\mathrm{gCaCO}_{3} \mathrm{l}^{-1}\right)$ & $1.7 \pm 0.3$ \\
Total alkalinity $\left(\mathrm{gCaCO}_{3} \mathrm{~L}^{-1}\right)$ & $2.8 \pm 0.5$ \\
Total ammonium nitrogen $\left(\mathrm{mgN}_{\mathrm{NHH}}{ }^{+} \mathrm{L}^{-1}\right)$ & $573.0 \pm 124.0$ \\
VFA $\left(\mathrm{mg} \mathrm{L}^{-1}\right)$ & $80.0 \pm 10.0$ \\
\hline
\end{tabular}

The digestate total solid (TS) content was not usable as it was (due to high turbidity) thus, in order to preliminarily assess the impact of the supernatant on microalgae, a TS reduction was performed with lab equipment (centrifugation at 10,161 $\mathrm{rcf}$ for $5 \mathrm{~min}$ ). The tested supernatant had a TS concentration of $73.3 \pm 4.3 \mathrm{mg} \mathrm{L}^{-1}$ (other parameters were unchanged). 


\subsection{Microalgae Strains, Maintenance and Analysis}

Scenedesmus obliquus and Chlorella vulgaris (wild type) were provided by Federico II University of Naples (Naples, Italy) and maintained in synthetic medium (ISO 8692) [32]. Optical density ( $\mathrm{OD}_{680}$ and $\mathrm{OD}_{750} \mathrm{~nm}$ ), cellular count and dry weight were carried out to monitor cellular growth. Optical density was measured with a spectrophotometer UV4 $100 \mathrm{He} \lambda$ os $\Upsilon$. Cellular count was monitored with a Bürke chamber on a Lika microscope using a $10 \mu \mathrm{L}$ aliquot. Dry weight was measured as total solid (TS) method (Equation (1)), while growth rate was calculated using Equation (2) [33]. All tests and analysis were carried out in duplicate.

$$
\text { Dry weight }\left(\mathrm{g}^{-1}\right)=\left(\mathrm{g}_{\mathrm{f} 2}-\mathrm{g}_{\mathrm{f} 1}\right) / 1_{\text {sample }}
$$

where $\mathrm{g}_{\mathrm{f} 2}$ is the weight of filter with sample after 2 days at $105^{\circ} \mathrm{C}, \mathrm{g}_{\mathrm{f} 1}$ is the filter weight.

$$
\text { Growth rate }(\mu)=(\ln \text { cell count } t / \ln \text { cell count } 0) / t
$$

\subsection{Petri Plate and Nile Red Qualitative Test}

Nile red coloring has been used as an alternative method to identify hydrophobic compound storage in several kinds of biomass, including animal cells, bacteria and microalgae [34-36]. This technique allows for qualitative and quantitative analysis and it represents a valid and alternative simple methodology for lipid determination compared to conventional solvent-based extraction methods [37]. For example, classic chemical methodology for lipid quantification uses thin-layer chromatography (TLC), gas chromatography (GC) or high-performance liquid chromatography (HPLC) associated with complete lipid extraction with solvents that require labor- and time-intensive activity that would not allow for easy large sample screening. Therefore, Nile red coloring stands as an ideal method for scale up screening [38]. Nile red drop coloring was applied on a Petri plate screening on microalgae colonies, where S. obliquus and C. vulgaris were tested on solid media (Agar agar 1.5\%, Sigma Aldrich, St. Louis, MO, USA) on Petri plates. According to the results of Zuliani at al. [9], Uggetti at al. [20] and Cho et al. [22], in this preliminary study, liquid digestate was diluted with tap water (DIG+TW) and ISO 8692 medium (DIG+ISO) with two different dilutions (1:10 and 1:5). OFMSW-WAS digestate's $\mathrm{NH}_{4}{ }^{+}$concentration $\left(573 \pm 124 \mathrm{mg} \mathrm{L}^{-1}\right)$ could inhibit microalgae proliferation; typically an ammonium concentration higher than $160 \mathrm{mg} \mathrm{L}^{-1}$ has a toxic effect on microalgae biomass growth [20,23], so strong dilution is required to have microalgae growth. Levels of $2.10 \mathrm{klux}$ and $3.9 \mathrm{klux}$ light irradiation were used to observe high and low illumination effects on microalgae growth in the selected media. After 8 days, Nile red reagent (Sigma Aldrich) was dropped on colonies to observe hydrophobic compounds accumulating in the microalgae biomass. Nile red drop coloration was applied, based on the Greenspan et al. publication [34], where a Nile red solution $\left(1000 \mu \mathrm{g} \mathrm{mL}^{-1}\right)$ was diluted 1:100 with acetone (Sigma Aldrich) and used for qualitative analysis on microalgae strains. Onto every colony was poured two Nile red solution drops; after $20 \mathrm{~min}$ in dark conditions the Petri plate was arranged on an ultraviolet plate to look at the Nile red fluorescence. All tests and analysis were performed in duplicate.

\subsection{Microalgae Growth: Batch Experiment Set-Up}

S. obliquus and C. vulgaris growth was tested in mixotrophic conditions on liquid OFMSW-WAS supernatant diluted by 1:5 with ISO 8692 or tap water (named DIG+ISO and DIG+TW respectively). Phototrophic growth conditions (ISO and TW) were used as control and all test conditions were carried out in duplicate. Inoculum concentration was $3.8 \pm 0.5$ million cells $\mathrm{mL}^{-1}$ and $6.0 \pm 1.0$ million cells $\mathrm{mL}^{-1}$ for S. obliquus and C. vulgaris, respectively. Mechanical agitation (10 rcf) and light irradiation (3.9 klux) were continuous, no air bubbling was added to have a more realistic microalgae growth and nitrogen uptake as well as to minimize ammonia removal by stripping. The test duration was 8 days and experiments were performed in $300 \mathrm{~mL}$ Kimax flasks at a stable temperature of $20^{\circ} \mathrm{C} \pm 1$ with 
initial inoculum diluted 1:5. Chlorophyll $a, b$ and carotenoids accumulation in microalgae biomass were measured at the end of each test [39]. Anionic and cationic chromatography analyses were performed to show anionic and cationic ion variation before (Table 2) and after microalgal treatment on OFMSW-WAS digestate. All test conditions and analyses were performed in duplicate.

Table 2. Characterization of initial cation and anion concentration in synthetic medium (ISO), tap water (TW), digestate diluted 1:5 with ISO and tap water (DIG+ISO and DIG+TW) before microalgae inoculum $(n=2)$.

\begin{tabular}{ccccc}
\hline & ISO & TW & DIG+TW & DIG+ISO \\
\hline $\mathrm{Cl}^{-}\left(\mathrm{mg} \mathrm{L}^{-1}\right)$ & $19.0 \pm 5.0$ & $8.0 \pm 1.0$ & $57.0 \pm 4.0$ & $64.0 \pm 1.0$ \\
$\mathrm{NO}_{2}^{-}\left(\mathrm{mg} \mathrm{L}^{-1}\right)$ & $0.0 \pm 0.0$ & $0.0 \pm 0.0$ & $0.0 \pm 0.0$ & $0.0 \pm 0.0$ \\
$\mathrm{NO}_{3}{ }^{-}\left(\mathrm{mg} \mathrm{L}^{-1}\right)$ & $0.5 \pm 0.2$ & $16.6 \pm 0.1$ & $12.2 \pm 0.2$ & $0.9 \pm 1.0$ \\
$\mathrm{PO}_{4}{ }^{-}\left(\mathrm{mg} \mathrm{L}^{-1}\right)$ & $0.5 \pm 0.0$ & $0.5 \pm 0.6$ & $14.5 \pm 0.1$ & $18.0 \pm 1.0$ \\
$\mathrm{SO}_{4}^{2-}\left(\mathrm{mg} \mathrm{L}^{-1}\right)$ & $6.1 \pm 0.2$ & $15.0 \pm 1.0$ & $13.5 \pm 0.3$ & $5.4 \pm 0.5$ \\
$\mathrm{Na}^{+}\left(\mathrm{mg} \mathrm{L}^{-1}\right)$ & $18.9 \pm 0.1$ & $8.6 \pm 0.3$ & $246.0 \pm 6.0$ & $253.0 \pm 1.0$ \\
$\mathrm{NH}_{4}^{+}\left(\mathrm{mg} \mathrm{L}^{-1}\right)$ & $1.6 \pm 0.1$ & $0.0 \pm 0.0$ & $196.0 \pm 13.0$ & $203.0 \pm 4.0$ \\
$\mathrm{~K}^{+}\left(\mathrm{mg} \mathrm{L}^{-1}\right)$ & $1.3 \pm 0.3$ & $1.3 \pm 0.2$ & $104.0 \pm 4.0$ & $106.0 \pm 1.0$ \\
$\mathrm{Mg}^{2+}\left(\mathrm{mg} \mathrm{L}^{-1}\right)$ & $3.8 \pm 0.1$ & $30.8 \pm 0.1$ & $184.0 \pm 19.0$ & $142.0 \pm 5.0$ \\
$\mathrm{Ca}^{2+}\left(\mathrm{mg} \mathrm{L}^{-1}\right)$ & $4.0 \pm 3.0$ & $39.0 \pm 7.0$ & $490.0 \pm 32.0$ & $417.0 \pm 9.0$ \\
\hline
\end{tabular}

\subsection{Analytical Method}

Tests for ammonia nitrogen, alkalinity, total and volatile solid (TS, VS), volatile fatty acids (VFA), pH and soluble chemical oxygen demand (sCOD) were performed according to APHA, APAT AWWA WET methods and ISA_CNR methodology $[40,41]$. Chlorophyll $a, b$ and carotenoids analysis were carried out with methanol extraction ( $5 \mathrm{~mL}$ for $2.5 \mathrm{~mL}$ of microalgae sample) [42] for $1 \mathrm{~h}$ at $60{ }^{\circ} \mathrm{C}$. After centrifugation at $1290 \mathrm{rcf}$ the supernatant obtained (methanol plus chlorophylls and carotenoids) was measured with a spectrophotometer at $\lambda 665.2 \mathrm{~nm}, 652.4 \mathrm{~nm}, 470 \mathrm{~nm}[43,44]$. Chlorophyll $a, b$ (Ch $a$ and $\mathrm{Ch} b$ ) and carotenoids quantification were obtained with Equations (3)-(5). The chlorophylls/carotenoids ratio analysis could be used as a marker to identify cultivation stress conditions $[9,45]$.

$$
\begin{aligned}
& \mathrm{Ch} \mathrm{a}=\left(16.72 \cdot \mathrm{OD}_{665.2}\right)-\left(9.16 \cdot \mathrm{OD}_{662.4}\right) \\
& \mathrm{Ch} \mathrm{b}=\left(34.09 \cdot \mathrm{OD}_{652.4}\right)-\left(15.28 \cdot \mathrm{OD}_{662.4}\right)
\end{aligned}
$$

$$
\text { Carotenoids }=\left(\left(1000 \cdot \mathrm{OD}_{470}\right)-(1.63 \cdot \mathrm{Ch} \mathrm{a})-(104.96 \cdot \mathrm{Ch} \mathrm{b})\right) / 221
$$

$\mathrm{Li}^{+}, \mathrm{Na}^{+}, \mathrm{NH}_{4}^{+}, \mathrm{K}^{+}, \mathrm{Mg}^{2+}$ and $\mathrm{Ca}^{2+}$ ions quantification on liquid medium was carried out with cationic chromatography (Dionex ED50 Elettrochemical detector, GS50 Gradient pump, LC25 Chromatography Oven, Dionex, Sunnyvale, CA, USA), with pre-column Guard Ion Pac CG12A (250 mm, Dionex), self-regeneration suppressor CSRS ULTRA II (4 mm, Dionex), separation column CS12A (2250 mm, Dionex); with $\mathrm{H}_{2} \mathrm{SO}_{4} 22 \mathrm{mN}$ eluent. Anionic chromatography (761 Compact IC, Metrohm) was carried out with IC anion separation column Metrosep A Supp 4-250 (Metrohom, Herisau, Switzerland), pre-column Guard Ion Pac AG18 (2.50 mm, Dionex), separation column AS18 (2250 $\mathrm{mm}$, Dionex) with $\mathrm{NaOH} 23 \mathrm{mM}$ eluent to identify $\mathrm{Cl}^{-}, \mathrm{NO}_{2}{ }^{-}, \mathrm{NO}_{3}{ }^{-}, \mathrm{PO}_{4}{ }^{3-}, \mathrm{SO}_{4}{ }^{2-}$ concentration. Ion removal was reported both as percentage and as $\mathrm{mg}_{\text {ion removed }}$ biomass ${ }^{-1} \mathrm{~d}^{-1}$ according to Equation (6) [46].

$$
\text { Ions removal rate }\left(\mathrm{mgX} \mathrm{g}_{\text {biomass }}{ }^{-1} \mathrm{~d}^{-1}\right)=\left(\mathrm{mgX}_{\mathrm{i}}-\mathrm{mgX}_{\mathrm{f}}\right) /\left(\mathrm{d} * \mathrm{~g}_{\text {biomass produced }}\right)
$$




\section{Discussion}

\subsection{Petri Plate: Nile Red Coloring Test}

Petri plate screening showed that $S$. obliquus cultivated on both digestates (DIG+ISO and DIG+TW), at both dilutions (1:5 and 1:10) and under both irradiations (2.1 klux and 3.9 klux) was inhibited, while C. vulgaris showed dense green colonies (Figure 1). S. obliquus inhibition of growth was also reported by Zuliani et al. [9], however they also reported inhibition for the growth of C. vulgaris. After microalgae colony formation, Nile red drop coloring was used to identify hydrophobic compounds stored inside the microalgae. Control colonies were not colored, and they were exposed on ultraviolet as blank. Figure 2 shows fluorescent emission by colonies after Nile red coloring: C. vulgaris cultivated on DIG+TW 1:5 showed the highest visible emissions, other colonies did not show significant emissions when compared to blanks.

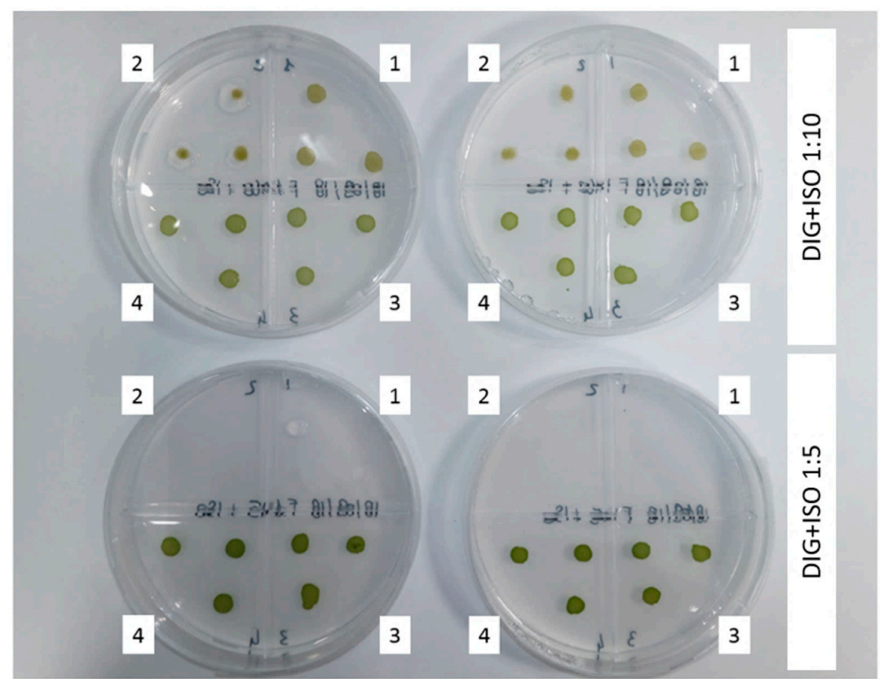

Figure 1. S. obliquus (1 and 2) and C. vulgaris (3 and 4) growth on Petri plate in DIG+ISO 1:5 and 1:10 test conditions.

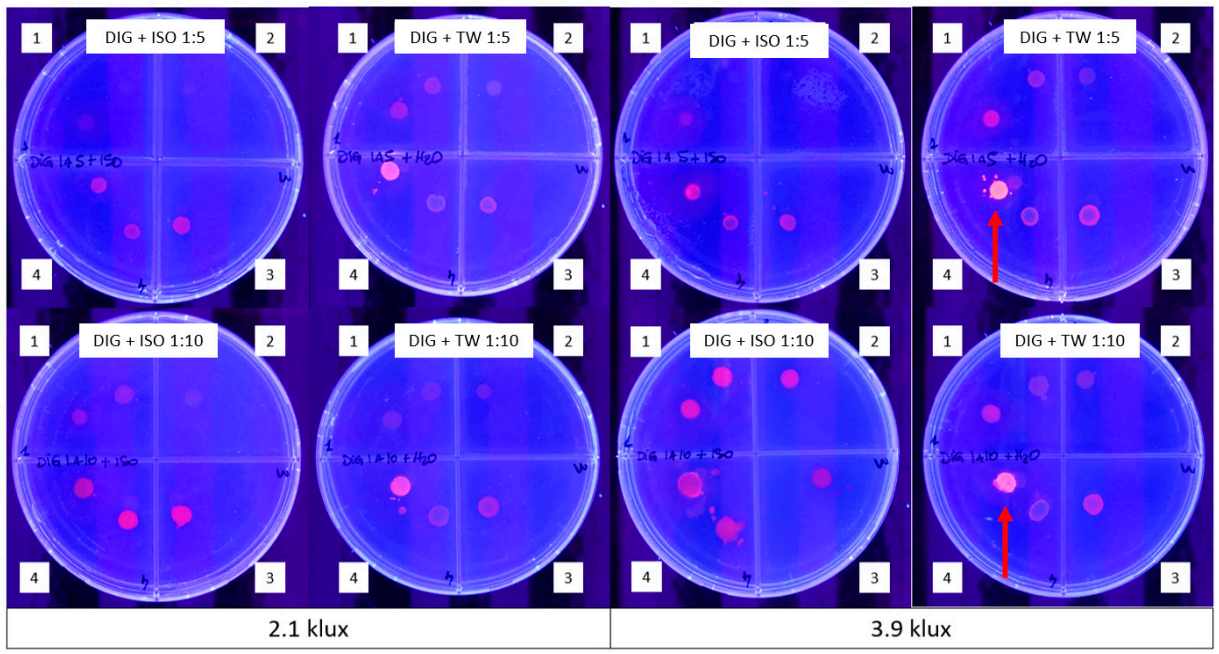

Figure 2. Nile red emissions after $20 \mathrm{~min}$ in the dark and with UV exposure of S. obliquus (1 and 2) and C. vulgaris ( 3 and 4 ) growth on Petri plate in control conditions (ISO and TW) and test conditions: DIG+ISO and DIG+TW 1:5 and 1:10. Microalgae growth was tested at two light irradiations, 2.10 klux and 3.9 klux. Arrows indicate fluorescent emission by colonies after Nile red coloring and ultraviolet exposure. 


\subsection{Batch Test: OFMSW-WAS Diluted 1:5 with ISO 8692 and Tap Water}

S. obliquus and C. vulgaris batch tests were carried out with OFMSW digestate diluted 1:5 with ISO 8692 (DIG+ISO) and tap water (DIG+TW). Control conditions were ISO 8692 (ISO) only and tap water (TW) only in mixotrophic growth conditions. C. vulgaris and S. obliquus cell count and $\mathrm{OD}_{680}$ showed C. vulgaris had higher growth in both media than S. obliquus (Table 3). These results confirmed the data previously obtained in Petri plate screening, where S. obliquus growth was inhibited (Figure 2). Similar results were obtained by Zuliani et al. [9], where C. vulgaris and S. obliquus were cultivated on filtered and autoclaved diluted digestate. In Zuliani et al. [9], C. vulgaris and S. obliquus growth were 55 and 15 million cells $\mathrm{mL}^{-1}$ respectively. In this study, C. vulgaris and S. obliquus $\mathrm{OD}_{680}$ results were lower than those obtained by Zuliani et al. [9] (2.0 and 1.8 times lower for C. vulgaris and S. obliquus, respectively). The difference could be associated with the experimental set-up difference, for example, in this study digestate was not sterilize and air bubbling was not applied in the batch test. Additionally, visual observation using an optical microscope (40×) showed a significant morphological change in C. vulgaris cells at the end of test, where $C$. vulgaris cells looked bigger than the initial cells. Probably this morphological change was associated with the accumulation of secondary high-value product in the cell [47].

Table 3. Cellular count, OD, dry weight and growth rate in stationary phase for C. vulgaris and S. obliquus in control conditions (ISO and TW) and test conditions (DIG+ISO and DIG+TW diluted 1:5) $(n=2)$.

\begin{tabular}{cccc}
\hline & & C. vulgaris & S. obliquus \\
\hline \multirow{3}{*}{ OD $_{680}$} & ISO & $0.40 \pm 0.02$ & $0.50 \pm 0.10$ \\
& TW & $0.05 \pm 0.01$ & $0.50 \pm 0.03$ \\
& DIG+ISO & $1.08 \pm 0.01$ & $0.04 \pm 0.03$ \\
& DIG+TW & $1.20 \pm 0.10$ & $0.37 \pm 0.05$ \\
\hline & ISO & $0.39 \pm 0.01$ & $0.54 \pm 0.04$ \\
OD $_{750}$ & TW & $0.07 \pm 0.01$ & $0.56 \pm 0.03$ \\
& DIG+ISO & $0.86 \pm 0.01$ & $0.11 \pm 0.02$ \\
& DIG+TW & $1.03 \pm 0.08$ & $0.42 \pm 0.04$ \\
\hline \multirow{4}{*}{ Million cells mL ${ }^{-1}$} & ISO & $32.00 \pm 8.00$ & $29.00 \pm 8.00$ \\
& TW & $6.00 \pm 2.00$ & $15.00 \pm 4.00$ \\
& DIG+ISO & $40.00 \pm 8.00$ & $2.70 \pm 0.20$ \\
& DIG+TW & $49.00 \pm 1.00$ & $4.90 \pm 0.90$ \\
\hline \multirow{5}{*}{ Dry weight $\left(\mathrm{g} \mathrm{L}^{-1}\right)$} & ISO & $0.04 \pm 0.01$ & $0.08 \pm 0.02$ \\
& TW & $0.01 \pm 0.00$ & $0.20 \pm 0.07$ \\
& DIG+ISO & $0.25 \pm 0.00$ & $0.16 \pm 0.00$ \\
& DIG+TW & $0.31 \pm 0.00$ & $0.23 \pm 0.01$ \\
\hline & ISO & $0.20 \pm 0.03$ & $0.25 \pm 0.30$ \\
$\mu\left(\mathrm{d}^{-1}\right)$ & TW & $0.00 \pm 0.04$ & $0.17 \pm 0.30$ \\
& DIG+ISO & $0.23 \pm 0.02$ & $0.00 \pm 0.00$ \\
& DIG+TW & $0.25 \pm 0.00$ & $0.03 \pm 0.20$ \\
\hline
\end{tabular}

C. vulgaris and S. obliquus dry weight at the end of the experiment (Table 3) showed similar biomass production in DIG+ISO and DIG+TW. These values are lower than those reported by Zuliani et al. [9], who obtained $2.00 \mathrm{~g} \mathrm{~L}^{-1}$ and $1.75 \mathrm{~g} \mathrm{~L}^{-1}$ for $C$. vulgaris and S. obliquus, respectively, but this could be due to medium sterilization and air insufflation that can help biomass growth [26]. Other studies reported a C. vulgaris biomass production of $0.6-0.7 \mathrm{~g} \mathrm{~L}^{-1}$ on diluted OFMSW digestate (1:10) after filtration at $0.2 \mu \mathrm{m}$ or preautoclaved [22,23]. Bjornsson et al. [48] using Scenedesmus $s p$. on swine manure digestate diluted with tap water observed a biomass production of $0.55 \mathrm{~g} \mathrm{~L}^{-1}$ and $\mathrm{NH}_{3}$ and $\mathrm{PO}_{4}{ }^{3-}$ total removal. Bjornsson et al. [48] suggested that some fresh water micro- and macronutrients could be absent in artificial medium or digestate and this did not permit microalgae growth. For example, 
$\mathrm{Mg}^{2+}$ is essential for microalgae growth. $\mathrm{Mg}^{2+}$ ion is an essential constituent of chlorophyll and its concentration in tap water could be high enough to facilitate microalgae proliferation.

Growth rate $(\mu)$ values (Table 3) showed that the growth rate of $C$. vulgaris was faster than the growth rate of S. obliquus in both DIG+ISO and DIG+TW. Values obtained for C. vulgaris were comparable with the ISO control condition. In addition, C. vulgaris showed a longer exponential growth phase compared to S. obliquus (4 days and 2 days, respectively). As reported by Massa et al. [49] who had tested S. obliquus on OFMSW digestate diluted 1:3 in synthetic medium, this strain showed no growth in the presence of a low digestate dilution as obtained in this study. Uggetti et al. [20] showed a S. obliquus growth rate between $0.04 \mathrm{~d}^{-1}$ and $0.90 \mathrm{~d}^{-1}$ on OFMSW digestate diluted 1:5 and 1:10, respectively. Veronesiv et al. [50] tested Chlorella sp. on agro-zootechnical ultrafiltered digestate 1:10 diluted and they obtained a growth rate of $0.2 \pm 0.01 \mathrm{~d}^{-1}$. Growth rates obtained in this study were comparable to those reported by these publications where digestate was autoclaved and filtered before use and microalgae cultivation was performed with air bubbling application.

\subsection{Nutrient Removal and Chlorophyll $a, b$ and Carotenoid Accumulation}

Petri plates test results encouraged batch testing with a supernatant diluted 1:5, with $199 \pm 9 \mathrm{mg} \mathrm{L}^{-1}$ initial ammonia concentration in both test conditions: DIG+ISO and DIG+TW. As reported in Figure 3, S. obliquus and C. vulgaris showed a good ammonia recovery capacity since half of the ammonia concentration was removed by microalgae. Nitrogen removal was directly related to microalgae metabolism activity.

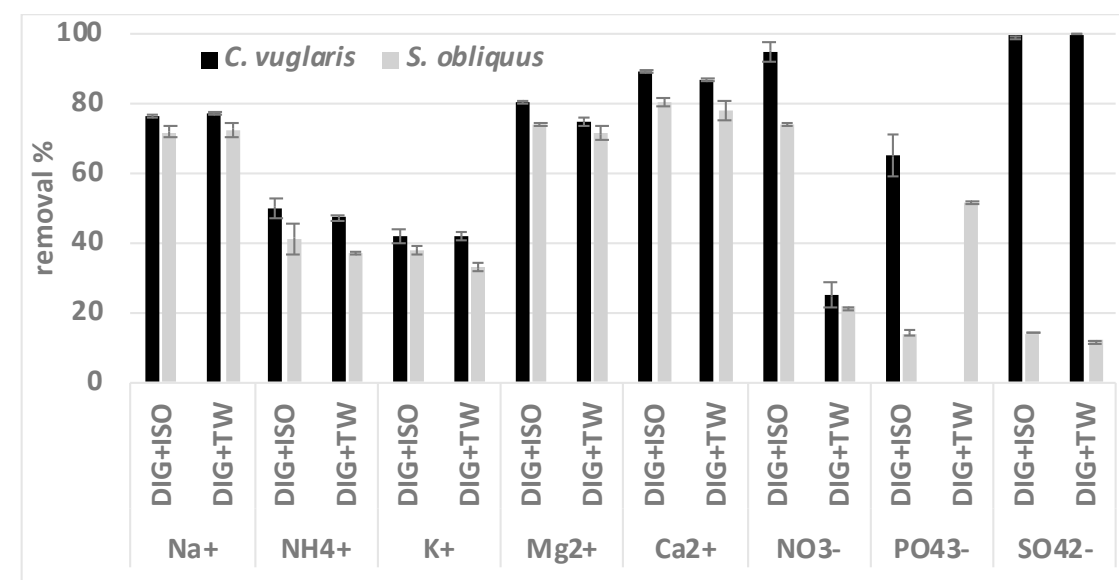

(a)

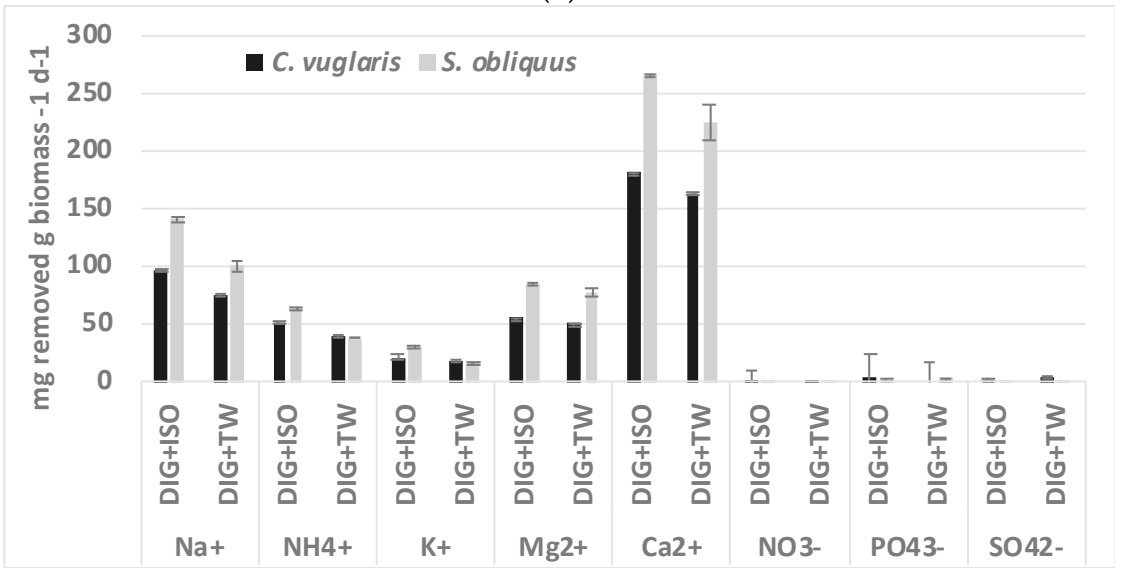

(b)

Figure 3. S. obliquus and C. vulgaris (a) nutrients removal percentage and (b) daily mg ions removal per $\mathrm{g}$ of biomass in OFMSW-WAS diluted 1:5 with ISO and in tap water conditions. $(n=2)$. 
The nitrogen removal values obtained in this study were lower than those reported by Massa et al. [49], Ledda et al. [51], Kim et al. [52], Xia and Murphy [19], Cai et al. [21], Cho et al. [22] and Gentili [53] where S. obliquus and C. vulgaris growth was carried out in several kinds of digestate, including OFMSW digestate. In those studies, they reported complete nitrogen removal. However, their microalgae cultivation was performed with air insufflation, so nitrogen removal was partially associated to ammonia stripping with a consequent ammonia loss to the atmosphere. In the present study, without air insufflation, C. vulgaris showed a better performance in terms of ammonia removal compared to $S$. obliquus in DIG+ISO condition, but the results obtained for ammonia removal on DIG+ISO and DIG+TW conditions were quite similar. Ledda et al. [51] and Nuñez et al. [54] highlighted that only $25-33 \%$ of nitrogen lost from medium was recycled in the microalgae biomass, and this percentage was comparable with data obtained with no air insufflation. Nitrate removal showed a similar trend to the Park et al. [55] study, where the nitrate decrease was directly linked with microalgae growth. Phosphate removal showed lower values than those reported in Gentili [53] and Riuz-Martinez et al. [56] where they obtained phosphate removal of 91-99\%. Sulfate removal was highest in $C$. vulgaris; this $\mathrm{SO}_{4}{ }^{2-}$ ion removal could be associated with $\mathrm{CO}_{2}$ fixations, $\mathrm{O}_{2}$ bioproduction, nitrate ion reduction and $\mathrm{N}_{2}$ fixation; all processes strictly associated with aerobic metabolism. S. obliquus's low sulphate removal efficiency could be associated with no cellular growth and intracellular substance release from biomass during the death stage of the growth curve [57,58]. So, C. vulgaris showed the best phytoremediation effect on digestate compared to S. obliquus during the batch test.

S. obliquus chlorophyll $a, b$ (Ch $a$ and $\mathrm{Ch} b$, respectively) and carotenoids analysis (Figure 4 ) showed similar values for ISO, TW, DIG+ISO and DIG+TW. On the other hand, C. vulgaris growth on digestate showed a carotenoids increase, while TW favored Ch $a$ and $\mathrm{Ch} b$ accumulation. Chlorophyll $a$ and total carotenoids ratio ( $\mathrm{Ch} a / \mathrm{Carot}_{\text {tot }}$ ) was measured to identify the stress growth condition linked to carotenoid storage: $C$. vulgaris' $\mathrm{Ch} a /$ Carot tot $_{\text {tot }}$ ratio was $6.6 \pm 0.8$ and $9.0 \pm 0.2$ on DIG+ISO and DIG+TW, respectively. These ratios were much higher than the 1.87 ratio reported by Zuliani et al. [9] for $C$. vulgaris. Chlorophyll and carotenoids analysis confirmed no stress or inhibition effects on C. vulgaris growth on OFMSW-WAS digestate inasmuch as it was in stress growth conditions (i.e., low light penetration or nutrient depletion) inducing $\mathrm{Ch} a$ degradation and carotenoids storage, with a strong decrease of $\mathrm{Ch} a /$ Carot $_{\text {tot }}$ ratio $[4,9]$.

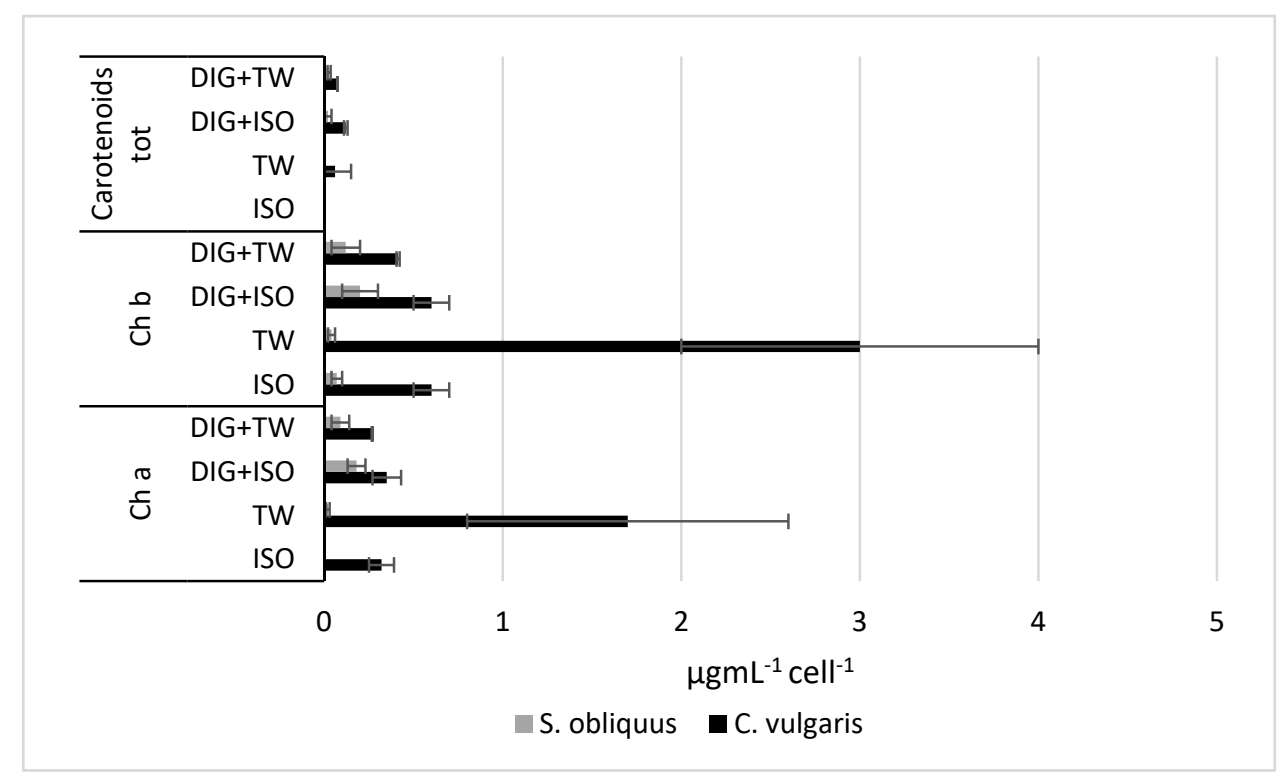

Figure 4. S. obliquus and C. vulgaris chlorophyll $a, b$ and carotenoids accumulation in ISO, TW, DIG+ISO and DIG+TW diluted 1:5 after 8 days. 


\section{Conclusions}

Petri plate cultivation showed that $C$. vulgaris had good growth capacity on OFMSW-WAS co-digestion digestate diluted at 1:10 and 1:5, and that S. obliquus growth was inhibited under these operational conditions. Petri plate screening pointed C. vulgaris as a potential strain that could grow on digestate with hydrophobic compound storage. Subsequently, C. vulgaris and S. obliquus were cultivated in batch test with OFMSW-WAS digestate 1:5 diluted with synthetic medium or tap water, without air insufflation in mixotrophic growth conditions. The results obtained confirmed C. vulgaris had superior growth capacity on digestate diluted 1:5: $0.31 \pm 0.00 \mathrm{~g} \mathrm{~L}^{-1}$ on DIG+ISO and $0.23 \pm 0.01 \mathrm{~g} \mathrm{~L}^{-1}$ on DIG+TW. The lower microalgae biomass production detected, compared to previous studies, was linked with no air insufflation and sterilization absence; however, the ammonium, nitrate, phosphorous and sulfate removal levels that were detected were similar to other studies where air bubbling was applied. Additionally, $C$. vulgaris cultivation removed $47.5 \pm 0.8 \%$ of the ammonia nitrogen, $65.0 \pm 6.0 \%$ of the phosphate, $95.0 \pm 3.0 \%$ of nitrate and $99.5 \pm 0.1 \%$ of the sulphate in the media. Overall, C. vulgaris showed a good phytoremediation effect on anaerobic co-digestion effluent and the morphological change detected during batch test suggested a secondary high value product storage that will be further analyzed.

Author Contributions: Conceptualization, P.S., C.C. and S.A.; methodology C.C.; validation, P.S., A.B., and C.C.; formal analysis, P.S. and A.B.; investigation, P.S. and A.B..; data curation, P.S.; writing-original draft preparation, P.S.; writing-review and editing, C.C., D.B. and S.A.; supervision, C.C. All authors have read and agreed to the published version of the manuscript.

Funding: This research received no external funding.

Acknowledgments: This research was supported by University Ca' Foscari of Venice initiative "Supporting Principal Investigators" for the project: "added-value chemical products and energy from bio-waste: (Anaerobic Digestion and Microalgae) integrated bio-phys-chem processes for a circular economy approach". Alto Trevigiano Servizi s.r.l. is also acknowledged for the hospitality.

Conflicts of Interest: The authors declare no conflict of interest, informed consent, or human or animal rights are applicable to this study.

\section{References}

1. Nkoa, R. Agricultural benefits and environmental risks of soil fertilization with anaerobic digestates: A review. Agron. Sustain. Dev. 2013, 34, 473-492. [CrossRef]

2. Levine, R.B.; Costanza-Robinson, M.S.; Spatafora, G.A. Neochloris oleoabundans grown on anaerobically digested dairy manure for concomitant nutrient removal and biodiesel feedstock production. Biomass Bioenergy 2010, 35, 40-49. [CrossRef]

3. Lukehurst, C.T.; Frost, P.; Al Seadi, T. Utilisation of digestate from biogas plants as biofertiliser. IEA Bioenergy 2010, 2010, 1-36.

4. Koutra, E.; Economou, C.N.; Tsafrakidou, P.; Kornaros, A.M. Bio-Based Products from Microalgae Cultivated in Digestates. Trends Biotechnol. 2018, 36, 819-833. [CrossRef]

5. Tyagi, V.K.; Fdez-Güelfo, L.; Zhou, Y.; Álvarez-Gallego, C.; Romero-García, L.I.; Ng, W.J. Anaerobic co-digestion of organic fraction of municipal solid waste (OFMSW): Progress and challenges. Renew. Sustain. Energy Rev. 2018, 93, 380-399. [CrossRef]

6. Chuka-Ogwude, D.; Ogbonna, J.; Moheimani, N.R. A review on microalgal culture to treat anaerobic digestate food waste effluent. Algal Res. 2020, 47, 101841. [CrossRef]

7. Lardon, L.; Hélias, A.; Sialve, B.; Steyer, J.-P.; Bernard, O. Life-Cycle Assessment of Biodiesel Production from Microalgae. Environ. Sci. Technol. 2009, 43, 6475-6481. [CrossRef]

8. Zhu, L. Microalgal culture strategies for biofuel production: A review. Biofuels Bioprod. Biorefining 2015, 9 , 801-814. [CrossRef]

9. Zuliani, L.; Frison, N.; Jelic, A.; Fatone, F.; Bolzonella, D.; Ballottari, M. Microalgae Cultivation on Anaerobic Digestate of Municipal Wastewater, Sewage Sludge and Agro-Waste. Int. J. Mol. Sci. 2016, 17, 1692. [CrossRef] 
10. Erkelens, M.; Ward, A.; Ball, A.S.; Lewis, D. Microalgae digestate effluent as a growth medium for Tetraselmis sp. in the production of biofuels. Bioresour. Technol. 2014, 167, 81-86. [CrossRef]

11. Chew, K.W.; Yap, J.Y.; Show, P.L.; Suan, N.H.; Juan, J.C.; Ling, T.C.; Lee, D.-J.; Chang, J.-S. Microalgae biorefinery: High value products perspectives. Bioresour. Technol. 2017, 229, 53-62. [CrossRef] [PubMed]

12. Heaven, S.; Milledge, J.J.; Zhang, Y. Comments on "Anaerobic digestion of microalgae as a necessary step to make microalgal biodiesel sustainable". Biotechnol. Adv. 2011, 29, 164-167. [CrossRef] [PubMed]

13. Sayedin, F.; Kermanshahi-Pour, A.; He, Q.S.; Tibbetts, S.M.; LaLonde, C.G.; Brar, S.K. Microalgae cultivation in thin stillage anaerobic digestate for nutrient recovery and bioproduct production. Algal Res. 2020, 47, 101867. [CrossRef]

14. Xu, J.; Zhao, Y.; Zhao, G.; Zhang, H. Nutrient removal and biogas upgrading by integrating freshwater algae cultivation with piggery anaerobic digestate liquid treatment. Appl. Microbiol. Biotechnol. 2015, 99, 6493-6501. [CrossRef] [PubMed]

15. Dickinson, K.; Bjornsson, W.J.; Garrison, L.; Whitney, C.; Park, K.; Banskota, A.; McGinn, P.J. Simultaneous remediation of nutrients from liquid anaerobic digestate and municipal wastewater by the microalga Scenedesmus sp. AMDD grown in continuous chemostats. J. Appl. Microbiol. 2014, 118, 75-83. [CrossRef]

16. Cai, T.; Park, S.Y.; Racharaks, R.; Li, Y. Cultivation of Nannochloropsis salina using anaerobic digestion effluent as a nutrient source for biofuel production. Appl. Energy 2013, 108, 486-492. [CrossRef]

17. Serejo, M.L.; Posadas, E.; Boncz, M.A.; Blanco, S.; García, P.; Muñoz, R. Influence of Biogas Flow Rate on Biomass Composition During the Optimization of Biogas Upgrading in Microalgal-Bacterial Processes. Environ. Sci. Technol. 2015, 49, 3228-3236. [CrossRef]

18. Tan, X.; Chu, H.; Zhang, Y.; Yang, L.; Zhao, F.; Zhou, X. Chlorella pyrenoidosa cultivation using anaerobic digested starch processing wastewater in an airlift circulation photobioreactor. Bioresour. Technol. 2014, 170, 538-548. [CrossRef]

19. Xia, A.; Murphy, J.D. Microalgal Cultivation in Treating Liquid Digestate from Biogas Systems. Trends Biotechnol. 2015, 34, 264-275. [CrossRef]

20. Uggetti, E.; Sialve, B.; Latrille, E.; Steyer, J.-P. Anaerobic digestate as substrate for microalgae culture: The role of ammonium concentration on the microalgae productivity. Bioresour. Technol. 2014, 152, 437-443. [CrossRef]

21. Cai, T.; Ge, X.; Park, S.Y.; Li, Y. Comparison of Synechocystis sp. PCC6803 and Nannochloropsis salina for lipid production using artificial seawater and nutrients from anaerobic digestion effluent. Bioresour. Technol. 2013, 144, 255-260. [CrossRef] [PubMed]

22. Cho, S.; Luong, T.T.; Lee, D.; Oh, Y.-K.; Lee, T. Reuse of effluent water from a municipal wastewater treatment plant in microalgae cultivation for biofuel production. Bioresour. Technol. 2011, 102, 8639-8645. [CrossRef] [PubMed]

23. Cho, S.; Lee, N.; Park, S.; Yu, J.; Luong, T.T.; Oh, Y.-K.; Lee, T. Microalgae cultivation for bioenergy production using wastewaters from a municipal WWTP as nutritional sources. Bioresour. Technol. 2013, 131, 515-520. [CrossRef] [PubMed]

24. Ioannou-Ttofa, L.; Puma, G.L.; Fatta-Kassinos, D. Treatment of winery wastewater by physicochemical, biological and advanced processes: A review. J. Hazard. Mater. 2015, 286, 343-368. [CrossRef]

25. Riaño, B.; Molinuevo, B.; García-González, M.C. Treatment of fish processing wastewater with microalgae-containing microbiota. Bioresour. Technol. 2011, 102, 10829-10833. [CrossRef]

26. Larsdotter, K.; Microbiology, E. Wastewater treatment with microalgae-A literature review. Vatten 2006, 62, 31-38. [CrossRef]

27. Abe, K.; Imamaki, A.; Hirano, M. Removal of nitrate, nitrite, ammonium and phosphate ions from water by the aerial microalga Trentepohlia aurea. J. Appl. Phycol. 2002, 14, 129-134. [CrossRef]

28. Li, X.; Yang, W.L.; He, H.; Wu, S.; Zhou, Q.; Yang, C.; Zeng, G.; Luo, L.; Lou, W. Responses of microalgae Coelastrella sp. to stress of cupric ions in treatment of anaerobically digested swine wastewater. Bioresour. Technol. 2018, 251, 274-279. [CrossRef]

29. Prajapati, S.K.; Malik, A.; Vijay, V.K. Comparative evaluation of biomass production and bioenergy generation potential of Chlorella spp. through anaerobic digestion. Appl. Energy 2014, 114, 790-797. [CrossRef]

30. Prajapati, S.K.; Kumar, P.; Malik, A.; Vijay, V.K. Bioconversion of algae to methane and subsequent utilization of digestate for algae cultivation: A closed loop bioenergy generation process. Bioresour. Technol. 2014, 158, 174-180. [CrossRef] 
31. Moretto, G.; Ardolino, F.; Piasentin, A.; Girotto, L.; Cecchi, F. Integrated anaerobic codigestion system for the organic fraaction of municipal solid waste and sewage sludge treatment: An Italian case study. J. Chem. Technol. Biotechnol. 2020, 95, 418-426. [CrossRef]

32. International Standard ISO. Fresh Water Algal Growth Inhibition Test with Unicellular Green Algae, 3rd ed.; ISO: Geneva, Switzerland, 2012.

33. Wang, L.; Min, M.; Li, Y.; Chen, P.; Chen, Y.; Liu, Y.; Wang, Y.; Ruan, R. Cultivation of Green Algae Chlorella sp. in Different Wastewaters from Municipal Wastewater Treatment Plant. Appl. Biochem. Biotechnol. 2009, 162, 1174-1186. [CrossRef] [PubMed]

34. Greenspan, P.; Mayer, E.P.; Fowler, S.D. Nile Red: A Selective Fluorescent Stain for Intracellular Lipid Droplets. J. Cell Biol. 1985, 100, 965-973. [CrossRef] [PubMed]

35. Zuriani, R.; Vigneswari, S.; Azizan, M.N.M.; Majid, M.I.A.; Amirul, A. A high throughput Nile red fluorescence method for rapid quantification of intracellular bacterial polyhydroxyalkanoates. Biotechnol. Bioprocess Eng. 2013, 18, 472-478. [CrossRef]

36. Doan, T.T.Y.; Obbard, J.P. Improved Nile Red staining of Nannochloropsis sp. J. Appl. Phycol. 2011, $23,895-901$. [CrossRef]

37. Alemán-Nava, G.S.; Cuellar-Bermudez, S.P.; Cuaresma, M.; Bosma, R.; Muylaert, K.; Ritmann, B.E.; Parra-Saldivar, R. How to use Nile Red, a selective fluorescent stain for microalgal neutral lipids. J. Microbiol. Methods 2016, 128, 74-79. [CrossRef]

38. Chen, W.; Zhang, C.; Song, L.; Sommerfeld, M.R.; Hu, Q. A high throughput Nile red method for quantitative measurement of neutral lipids in microalgae. J. Microbiol. Methods 2009, 77, 41-47. [CrossRef]

39. Jalal, K.; Shamsuddin, A.; Rahman, M.; Nurzatul, N.; Rozihan, M. Growth and Total Carotenoid, Chlorophyll a and Chlorophyll b of Tropical Microalgae (Isochrysis sp.) in Laboratory Cultured Conditions. J. Boil. Sci. 2013, 13, 10-17. [CrossRef]

40. APAT-IRSA/CNR. Metodologie analitiche per il controllo della qualità delle acque. Poligr e Zecca Dello Stato Roma Italy 2003, 29, 575-581.

41. APHA; AWWA; WEF. Standard Methods for Examination of Water and Wastewater, 22nd ed.; Public Health Association: Washington, DC, USA, 2012; p. 1360. ISBN 978-087553-013-0. Available online: http://www. standardmethods.org/ (accessed on 17 September 2020).

42. Miazek, K.; Ledakowicz, S. Chlorophyll extraction from leaves, needles and microalgae: A kinetic approach. Int. J. Agric. Biol. Eng. 2013, 6, 107-115. [CrossRef]

43. Lichtenthaler, H.K.; Buschmann, C. Chlorophylls and carotenoids: Measurement and characterization by UV-VIS spectroscopy. Curr. Protoc. Food Anal. Chem. 2001, 1, F4-3. [CrossRef]

44. Prajapati, S.K.; Kaushik, P.; Malik, A.; Vijay, V.K. Phycoremediation and biogas potential of native algal isolates from soil and wastewater. Bioresour. Technol. 2013, 135, 232-238. [CrossRef] [PubMed]

45. He, Q.; Yang, H.; Wu, L.; Hu, C. Effect of light intensity on physiological changes, carbon allocation and neutral lipid accumulation in oleaginous microalgae. Bioresour. Technol. 2015, 191, 219-228. [CrossRef] [PubMed]

46. Powell, E.O. Growth Rate and Generation Time of Bacteria, with Special Reference to Continuous Culture. J. Gen. Microbiol. 1956, 15, 492-511. [CrossRef] [PubMed]

47. Pancha, I.; Chokshi, K.; George, B.; Ghosh, T.; Paliwal, C.; Maurya, R.; Mishra, S. Nitrogen stress triggered biochemical and morphological changes in the microalgae Scenedesmus sp. CCNM 1077. Bioresour. Technol. 2014, 156, 146-154. [CrossRef] [PubMed]

48. Bjornsson, W.J.; Nicol, R.W.; Dickinson, K.E.; McGinn, P.J. Anaerobic digestates are useful nutrient sources for microalgae cultivation: Functional coupling of energy and biomass production. J. Appl. Phycol. 2013, 25, 1523-1528. [CrossRef]

49. Massa, M.; Buono, S.; Langellotti, A.L.; Castaldo, L.; Martello, A.; Paduano, A.; Sacchi, R.; Fogliano, V. Evaluation of anaerobic digestates from different feedstocks as growth media for Tetradesmus obliquus, Botryococcus braunii, Phaeodactylum tricornutum and Arthrospira maxima. New Biotechnol. 2017, 36, 8-16. [CrossRef]

50. Veronesiv, D.; D’Imporzano, G.; Salati, S.; Adani, F. Pre-treated digestate as culture media for producing algal biomass. Ecol. Eng. 2017, 105, 335-340. [CrossRef] 
51. Ledda, C.; Idà, A.; Allemand, D.; Mariani, P.; Adani, F. Production of wild Chlorella sp. cultivated in digested and membrane-pretreated swine manure derived from a full-scale operation plant. Algal Res. 2015, 12, 68-73. [CrossRef]

52. Kim, G.-Y.; Yun, Y.-M.; Shin, H.-S.; Kim, H.-S.; Han, J.-I. Scenedesmus-based treatment of nitrogen and phosphorus from effluent of anaerobic digester and bio-oil production. Bioresour. Technol. 2015, 196, 235-240. [CrossRef] [PubMed]

53. Gentili, F.G. Microalgal biomass and lipid production in mixed municipal, dairy, pulp and paper wastewater together with added flue gases. Bioresour. Technol. 2014, 169, 27-32. [CrossRef] [PubMed]

54. Nuñez, V.J.; Voltolina, D.; Nieves, M.; Piña, P.; Medina, A.; Guerrero, M. Nitrogen budget in Scenedesmus obliquus cultures with artificial wastewater. Bioresour. Technol. 2001, 78, 161-164. [CrossRef]

55. Park, J.; Jin, H.-F.; Lim, B.-R.; Park, K.-Y.; Lee, K. Ammonia removal from anaerobic digestion effluent of livestock waste using green alga Scenedesmus sp. Bioresour. Technol. 2010, 101, 8649-8657. [CrossRef]

56. Ruiz-Martinez, A.; Garcia, N.M.; Romero, I.; Seco, A.; Ferrer, J. Microalgae cultivation in wastewater: Nutrient removal from anaerobic membrane bioreactor effluent. Bioresour. Technol. 2012, 126, 247-253. [CrossRef] [PubMed]

57. Qin, L.; Wei, D.; Wang, Z.; Alam, M.A. Advantage Assessment of Mixed Culture of Chlorella vulgaris and Yarrowia lipolytica for Treatment of Liquid Digestate of Yeast Industry and Cogeneration of Biofuel Feedstock. Appl. Biochem. Biotechnol. 2019, 187, 856-869. [CrossRef] [PubMed]

58. Mohammadi, M.; Mowla, D.; Esmaeilzadeh, F.; Ghasemi, Y. Cultivation of microalgae in a power plant wastewater for sulfate removal and biomass production: A batch study. J. Environ. Chem. Eng. 2018, 6, 2812-2820. [CrossRef]

(C) 2020 by the authors. Licensee MDPI, Basel, Switzerland. This article is an open access article distributed under the terms and conditions of the Creative Commons Attribution (CC BY) license (http://creativecommons.org/licenses/by/4.0/). 